\title{
PATTERNS OF SURFACE BURROW PLUGGING IN A COLONY OF BLACK-TAILED PRAIRIE DOGS OCCUPIED BY BLACK-FOOTED FERRETS
}

\author{
David A. Eads ${ }^{1}$ and Dean E. Biggins ${ }^{2}$
}

\begin{abstract}
Black-tailed prairie dogs (Cynomys ludovicianus) can surface-plug openings to a burrow occupied by a black-footed ferret (Mustela nigripes). At a coarse scale, surface plugs are more common in colonies of prairie dogs occupied by ferrets than in colonies without ferrets. However, little is known about spatial and temporal patterns of surface plugging in a colony occupied by ferrets. In a 452-ha colony of black-tailed prairie dogs in South Dakota, we sampled burrow openings for surface plugs and related those data to locations of ferrets observed during spotlight surveys. Of 67,574 burrow openings in the colony between June and September 2007, 3.7\% were plugged. In a colony-wide grid of $80 \mathrm{~m} \times 80 \mathrm{~m}$ cells, the occurrence of surface plugging ( $\geq 1$ opening plugged) was greater in cells used by ferrets $(93.3 \%$ of cells) than in cells not observably used by ferrets (70.6\%). Rates of surface plugging (percentages of openings plugged) were significantly higher in cells used by ferrets (median $=3.7 \%$ ) than in cells without known ferret use (median $=$ $3.2 \%$ ). Also, numbers of ferret locations in cells correlated positively with numbers of mapped surface plugs in the cells. To investigate surface plugging at finer temporal and spatial scales, we compared rates of surface plugging in 20-mradius circle-plots centered on ferret locations and in random plots 1-4 days after observing a ferret (Jun-Oct 2007 and 2008). Rates of surface plugging were greater in ferret-plots (median $=12.0 \%$ ) than in random plots $($ median $=0 \%)$. For prairie dogs and their associates, the implications of surface plugging could be numerous. For instance, ferrets must dig to exit or enter plugged burrows (suggesting energetic costs), and surface plugs might influence microclimates in burrows and consequently influence species that cannot excavate soil (e.g., fleas that transmit the plague bacterium Yersinia pestis).
\end{abstract}

Resumen.-Los perros llaneros de cola negra (Cynomys ludovicianus) pueden tapar al nivel de la superficie las madrigueras ocupadas por hurones de patas negras (Mustela nigripes). En la escala de la colonia entera, los taponamientos al nivel de la superficie son más comunes en las colonias de perros llaneros ocupadas por hurones que en las colonias sin hurones. Sin embargo, poco se conoce en cuanto a los patrones espaciales y temporales de los taponamientos al nivel de la superficie en las colonias ocupadas por hurones. En una colonia de 452 hectáreas de perros llaneros de cola negra en Dakota del Sur, realizamos un muestreo de las madrigueras con taponamientos al nivel de la superficie y relacionamos esa información con los lugares en donde se observaron hurones durante los monitoreos con reflectores. De las 67,574 madrigueras en una colonia que se localizaron de junio a septiembre de 2007 , el $3.7 \%$ estaban tapadas. En una colonia en la que se trazó una cuadrícula con celdas de $80 \mathrm{~m} \times 80 \mathrm{~m}$, la incidencia de taponamientos hechos al nivel de la superficie ( $\geq 1$ entrada taponada) fue mayor en las celdas usadas por los hurones (93.3\% de las celdas) que en las celdas en las que no se observaba que éstos las usaran (70.6\%). Las tasas de taponamientos al nivel de la superficie (las proporciones de madrigueras tapadas) fue significativamente mayor en las celdas usadas por los hurones $($ mediana $=3.7 \%$ ) que en aquellas que no usaban los hurones (mediana $=3.2 \%$ ). También, el número de ubicaciones de los hurones en las celdas tuvo una correlación positiva con el número de taponamientos al nivel de la superficie ubicados en las celdas. Para investigar espacialmente los taponamientos al nivel de la superficie en una escala temporal más fina, comparamos las tasas de este tipo de taponamientos en terrenos con radios circulares de 20 metros centrados en los lugares donde se ubicaron hurones y en ubicaciones aleatorias de 1 a 4 días después de haber observado un hurón (junio a octubre de 2007 a 2008). Las tasas de taponamientos al nivel de la superficie fueron mayores en los terrenos de los hurones (mediana $=12.0 \%$ ) que en los tomados al azar (mediana $=0 \%$ ). Para los perros llaneros y las especies con las que interactúan, las implicaciones del taponamiento hecho al nivel superficial podrían ser numerosas. Por ejemplo, los hurones tendrían que excavar tanto para salir de las madrigueras tapadas como para entrar en ellas (infiriendo un costo energético) y los taponamientos hechos al nivel de la superficie podrían influir en los microclimas de las madrigueras, y por ende influir en las especies que no pueden excavar (e.g., las pulgas que transmiten Yersinia pestis).

Prairie dogs (Cynomys) are colonial, sciurid rodents of the plains and intermountain grasslands of western North America (Hoogland 1995). These rodents serve many ecological functions and their colonies are crucial components of grassland ecosystems (Kotliar et al. 2006). For example, prairie dogs are prey for many predators, dig burrows that are used by 
many species, and graze on and clip vegetation in ways that facilitate productivity of forbs, while reducing shrub encroachment. Since the early 1900s, prairie dog abundance has declined, primarily due to human persecution and introduction of the plague bacterium Yersinia pestisa pathogen that can decimate prairie dog populations. Currently, prairie dogs are so few that they cannot serve their historic ecological functions at most sites (McDonald et al. 2011), and some associated species have declined in abundance, including the black-footed ferret (Mustela nigripes) — a specialized predator of prairie dogs that is highly endangered (Miller et al. 1996). Continued study of this predatorprey system is needed to facilitate conservation efforts for prairie dogs and ferrets alike.

Little is known about the defenses used by prairie dogs against ferrets and how those defenses might influence the behaviors of ferrets. Here, we address one defense used by prairie dogs against ferrets-burrow plugging. Like many burrowing rodents, black-tailed prairie dogs (Cynomys ludovicianus; hereafter "prairie dogs") can use substrate to bury semifossorial predators in burrows (Henderson et al. 1969:21). For example, prairie dogs have been observed to plug openings to a burrow at which they detected a black-footed ferret (hereafter "ferret"), which temporarily confined the ferret belowground (Hillman 1968, Henderson et al. 1969, Fortenbery 1972, Martin et al. 1984, Jachowski 2007). Although a ferret can remove soil plugs near the surface (Henderson et al. 1969) and in burrow tunnels belowground (Biggins et al. 2012b), high rates of plugging would suggest considerable energetic expense for both prairie dogs and ferrets (Biggins et al. 2012a). For example, Biggins et al. (2012a) estimated that in excavating soil from a burrow likely plugged by white-tailed prairie dogs (C. leucurus) before they hibernated, a female ferret removed $16.8 \mathrm{~kg}$ of soil, >23 times the average weight for female ferrets $(0.71 \mathrm{~kg}-$ Miller et al. 1996).

Former investigations of surface plugging by prairie dogs included surveys in colonies occupied by ferrets and colonies in which ferrets were not observed. Although surface plugs were found in all colonies, they were more common in ferret-occupied colonies (Hillman and Linder 1973, Biggins et al. 2012b). Within ferret-occupied colonies, Hillman and Linder (1973:15) gained the impression that patches of surface plugs in portions of a colony are indicative of ferret activity. Field data supporting that notion are sparse and largely qualitative, but they have prompted daytime searches for plugs to survey for ferrets and accommodate Section 7 of the Endangered Species Act (i.e., to determine if a proposed action might harm ferrets; Clark 1989).

Prairie dogs can plug burrows occupied by ferrets, but little is known about how often they do so and at what spatial scales such behavior is best interpreted. We investigated surface plugging by prairie dogs in a ferretoccupied colony in South Dakota. We sampled burrow openings in the colony for surface plugs and related those data to data on space use by ferrets as indicated by sightings of ferrets during spotlight surveys. This assessment involved spatial analyses of relationships between ferret presence and numbers of surface plugs at varying scales. We used this assessment to more thoroughly investigate the hypothesis of Hillman and Linder (1973) that patches of surface plugs in portions of a colony are indicative of ferret activity.

\section{Methods}

During 13 June-10 October 2007 and 11 June-27 September 2008, we monitored 21 adult ferrets in a 452-ha colony of prairie dogs in the Conata Basin of southwestern South Dakota (Fig. 1). Five of the 21 ferrets inhabited the colony in 2007 and 2008, whereas each of the remaining 16 ferrets inhabited the colony during either 2007 or 2008. Densities of adult ferrets were similar each year (12 in 2007 and 14 in $2008=0.03$ per ha). To collect locations of ferrets, we conducted spotlight surveys, primarily from midnight to sunrise (Eads et al. 2012a), accumulating coordinates of ferrets using handheld global positioning units (Biggins et al. 2006).

\section{Analysis of Data at Moderate Spatial and Temporal Scales}

Between July and mid-September 2007, a team mapped openings to prairie dog burrows using Trimble ${ }^{\circledR}$ CMT MC-V Global Positioning System receivers (Trimble Navigation Limited, Sunnyvale, CA). We classified burrow openings as open or plugged at the surface. Plugs can be removed by ferrets (Henderson et al. 1969), but those that are not removed 


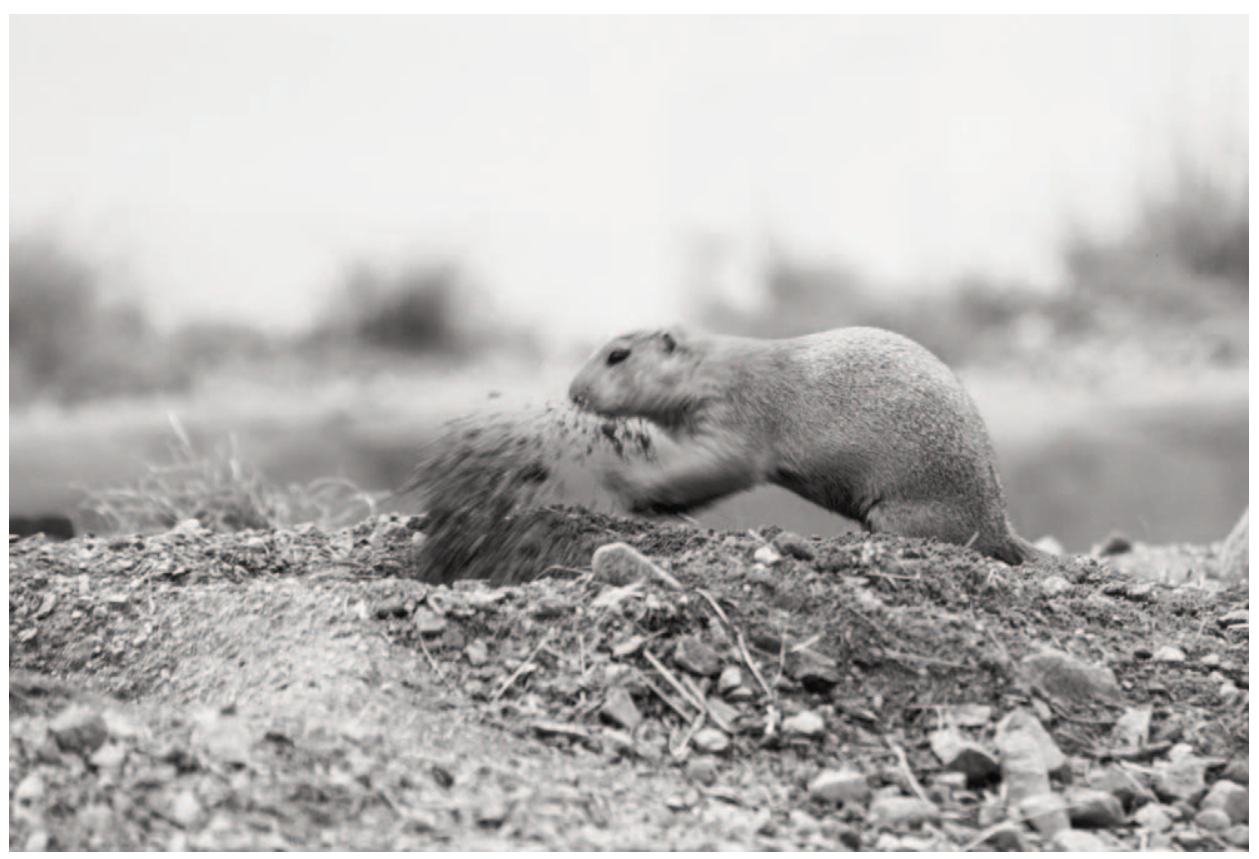

Fig. 1. We investigated plugging of burrow openings (surface plugging) by black-tailed prairie dogs (Cynomys ludovicianus) in response to black-footed ferrets (Mustela nigripes) in a 452-ha colony of prairie dogs in the Conata Basin, Buffalo Gap National Grasslands, South Dakota. Here, a black-tailed prairie dog surface-plugs a burrow opening (photo used with permission: ๑) danheller.com).

presumably degrade from fresh deposits of soil in a burrow opening to bare mounds or patches of soil which become revegetated. Mounds without burrow openings can remain identifiable for years (DEB unpublished data), producing a continuum of transitional phases that render categorical classification of plugs difficult (and variable among studies; Biggins et al. 2012b). We classified an opening as plugged only if it contained fresh deposits of soil. Fresh soil indicated that a prairie dog recently created the plug, but the exact age of a plug was unknown.

We conducted spatial analyses using data from the spotlight surveys and the mapping effort. First, we overlaid a grid of $80 \mathrm{~m} \times 80 \mathrm{~m}$ cells on the colony and restricted the grid to cells encompassing $\geq 1$ mapped burrow opening (open or plugged). This grid cell size reduced correlations for counts of burrow openings in neighboring cells, thus reducing spatial autocorrelation in the colony map (Eads 2009); this helped to reduce type I error in a regression analysis described below. Next, we counted numbers of (1) burrow openings without surface plugs and (2) surface-plugged openings in each cell. We then counted numbers of ferret locations (spotlight observations) in each cell, creating grid data for the 2007 spotlight surveys alone (given we did not remap the burrow openings in 2008). We conducted 3 analyses using the 2007 grid data. For an analysis considering ferret occupancy and presence or absence of surface plugs (binomial variable), we used Program R (version 2.11.1) to complete a $\chi^{2}$ test $(\alpha=0.05)$. This test compared proportions of cells that contained at least one surface plug for cells used by ferrets versus cells not observably used by ferrets.

Second, again considering ferret occupancy, we compared rates of surface plugging (proportions of openings plugged) in cells used or not observably used by ferrets. These data were nonnormal (Shapiro-Wilk test: $P<0.001$ ). Thus, for comparison among cells with or without a ferret location, we used a distribution-free Mann-Whitney $U$ test in Program R $(\alpha=0.05)$.

Third, to consider intensity of use by ferrets, we related counts of ferret locations in cells (covariate) to counts of surface plugs using linear least-squares regression in Program R, with $\alpha$ $\leq 0.05$ judged as significant. Numbers of plugged openings in cells might be correlated 


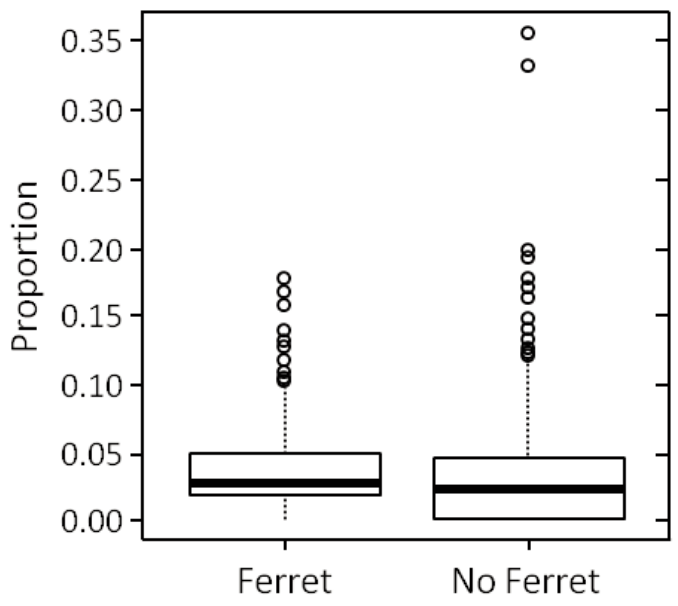

Fig. 2. Boxplot of rates of surface plugging (proportions of burrow openings plugged) in $80 \mathrm{~m} \times 80 \mathrm{~m}$ cells containing one or more observations (Ferret) or no observations (No Ferret) of black-footed ferrets (Mustela nigripes). The grid of cells overlaid a 452-ha colony of black-tailed prairie dogs (Cynomys ludovicianus) in the Conata Basin, South Dakota, June-October 2007.

with numbers of openings in the cells (with more openings, there can be more surface plugs). Also, densities of burrow openings positively correlate with densities of prairie dogs, and surface plugging is perhaps more likely if prairie dogs are abundant in an area (given that more prairie dogs are there to create surface plugs; Biggins et al. 1993, Johnson and Collinge 2004, Chipault 2010). For these reasons, in each model we included counts of nonplugged burrow openings in the grid cells as a second (control) covariate. For both years, regression adjusted Moran's I analyses (inverse distance weighting) of the residuals of linear least-squares models indicated spatial autocorrelation (both $P<0.001$; Cliff and Ord 1981). Thus, we used Gaussian spatial autoregressive (SAR) models with inverse distance weighting for interpretation (e.g., Bonham and Reich 1999, Lichstein et al. 2002, Reich and Bonham 2001).

Fine-Scale Spatial and Temporal Analysis

For a finer-scale analysis in our study colony, we used daytime surveys for surface plugs in 20-m-radius circle-plots (0.13 ha) centered on (1) burrow openings at which we located ferrets and (2) randomly selected burrow openings (2007-2008). Hereafter, these plots are referred to as ferret plots and random plots. Daytime surveys involved counting numbers of burrow openings and surface plugs in the plots within
1-4 days of observing a ferret, thereby allowing estimation of surface plugging rates (presented as proportions of openings plugged). In this analysis, we had recently observed a ferret in the ferret-plots $(\bar{x}=0.83$ days, $\mathrm{SD}=1.06$; cf. the grid analysis, for which we did not know the interval between ferret-occurrence and plugging). For the daytime data, rates of surface plugging deviated from normality for ferret plots and random plots (Shapiro-Wilk tests: both $P<0.001)$, so we used a distribution-free Mann-Whitney $U$ test in Program R $(\alpha=0.05)$ to perform the comparison.

\section{REsults}

In the 452-ha colony, the team mapped 67,574 burrow openings (open + plugged) (149.5 per ha). Of these openings, $3.7 \%$ were surface-plugged (5.59 per ha).

\section{Analysis of Data at Moderate Spatial and Temporal Scales}

For the broadscale analyses of grid cells, the presence of surface plugging was greater in cells used by ferrets (93.3\% of cells) than in cells not observably used by ferrets $\left(70.6 \% ; \chi^{2}{ }_{1}=45.26\right.$, $P=0.001$ ). Also, rank values for rates of surface plugging were greater in cells used by ferrets (median $=3.7 \%$ of openings plugged) than cells not used by ferrets (3.2\%; Fig. 2 ; $U=51,703, P<0.001)$. Lastly, numbers of surface plugs in cells correlated positively with numbers of ferret locations in the cells (SAR model: $F_{2,776}=26.52, P<0.001$ ). Thus, surface plugs were more common and abundant in areas of the colony selected by ferrets.

\section{Fine-Scale Spatial and Temporal Analysis}

For the finer-scale analysis, we sampled 118 ferret plots in 2007 and 96 ferret plots (and random plots) in 2008. These samples included $26 \%$ of the spotlight observations for ferrets in 2007 and $23 \%$ of the observations in 2008 . Rank values for rates of surface plugging were greater in the ferret plots $($ median $=12.0 \%)$ than in random plots (median $=0 \% ; U=41,749$, $P<0.001)$. Thus, plugging rates were greater near ferret locations than at random locations in the colony (Fig. 3).

\section{Discussion}

In the map of the 452-ha colony of prairie dogs (occupied by ferrets), $3.7 \%$ of burrow 


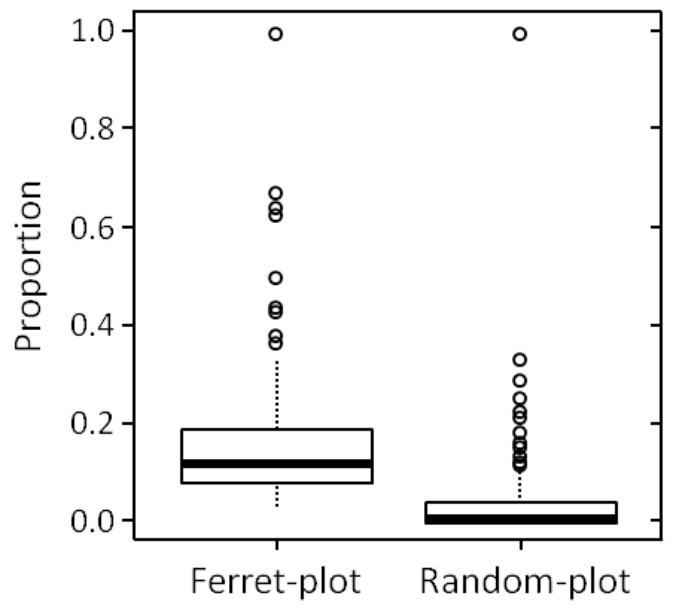

Fig. 3. Boxplot of rates of surface plugging (proportions of burrow openings plugged) in 0.13-ha circle-plots centered on burrow openings at which a black-footed ferret (Mustela nigripes) was observed and random burrow openings in a 452-ha colony of black-tailed prairie dogs (Cynomys ludovicianus) in the Conata Basin, South Dakota, during JuneOctober 2007-2008.

openings were surface-plugged. This proportion contrasts with that reported by Hillman and Linder (1973) who found 15\%-25\% of burrow openings surface-plugged in relatively small South Dakota colonies occupied by ferrets $(<16.2$ ha). Hillman and Linder collected data on colonies approximately 6 times smaller than the average size of a ferret home range ( 90-100 ha; Jachowski et al. 2010, Livieri and Anderson 2012), and each colony was occupied by one female ferret. Thus, at least one ferret was likely to have used most (or all) of each study colony (to acquire sufficient prey), which could have stimulated very high rates of surface burrow plugging by prairie dogs in the Hillman and Linder study. In contrast, we studied ferrets inhabiting a 452-ha colony, portions of which were not observably used by ferrets during our study (see Fig. 2 in Eads et al. $201 \mathrm{lb}$ ); rates of surface plugging were low in areas not used by ferrets, which reduced the overall rate (proportion) of burrow openings plugged in the colony. In addition, we do not know how Hillman and Linder classified plugs; classification of nonvegetated mounds as plugged burrow openings also could have elevated their proportions relative to ours.

Our rate of $3.7 \%$ for surface plugging also contrasts with the results of Biggins et al. (2012b), who reported a surface-plugging rate of $18.9 \%$ along transects in colonies occupied by ferrets (these researchers sampled our study site the year after our study). We attribute this difference primarily to the differing definitions of a plugged opening. In 2009, Biggins et al. classified nonvegetated mounds without openings as plugged, whereas we did not in 2007-2008. Instead we classified openings as plugged only if a fresh soil deposit blocked the opening. We suggest that investigators consider their study objectives when defining a plugged opening. If a general, long-term spatial trend is of interest (e.g., Biggins et al. 2012 b), the definition might include all nonvegetated mounds without openings. In contrast, if investigators are interested in accumulating data on fresh plugs, then the definition should be limited to fresh soil deposits.

In our moderate-scale analysis (the grid), plugs were more common and plugging rates were greater in cells used by ferrets than in cells not observably used by ferrets, and numbers of ferret locations positively correlated with numbers of surface plugs in grid cells. Also, as discussed below, during daytime surveys of ferret plots and random plots $(0.13 \mathrm{ha})$, rates of surface plugging were greater in the ferret plots. Thus, fine-scale patterns of surface plugging provided information about locations of ferrets in the colony, as proposed by Hillman and Linder (1973).

The 0.13-ha plots provided data that correspond with previous rates and perhaps provide insight into fine-scale spatial patterns of surface plugging by prairie dogs. First, notwithstanding potential interstudy differences in the definition of a plugged opening, the rate of surface plugging in random plots (median $=0 \%$, $\bar{x}=3.3 \%$ ) resembles rates found in colonies without ferrets (4\% in Clark et al. 1982; $3 \%$ in Biggins et al. 2012b). Thus, it seems that prairie dogs plug few openings in colonies without ferrets and in small areas of a ferret-occupied colony that are not currently used by a ferret. Second, the higher rate of surface plugging in ferret plots $($ median $=12.0 \%, \bar{x}=15.4 \%)$ resembles rates reported for relatively small colonies with ferrets $(15 \%-25 \%$ in $<16$-ha colonies_-Hillman and Linder 1973), a portion of a colony occupied by Siberian polecats (Mustela eversmanii) released as investigational surrogates for ferrets $(16.5 \%$ in a 9 -ha plot-Biggins et al. 1991), and transects completed by Biggins et al. (2012b) in ferret-occupied colonies (including our study colony) (18.9\%). It seems 
prairie dogs surface-plug numerous openings in colonies with ferrets and, in particular, in areas of the colonies actively or recently used by a ferret.

Surface plugging is one potential defense used by prairie dogs against ferrets (Henderson et al. 1969:21). Ferrets can remove surface plugs, suggesting plugs do not directly stop attacks from ferrets. However, plugging might reduce predation risk in indirect ways. Ferrets seem to favor burrow systems with multiple openings (Biggins 2012). By surface-plugging openings in the area currently used by a ferret, a prairie dog family (or families) could enclose or reduce connections to the complex burrow system(s) used by the ferret. To reopen the complex burrow system(s), the ferret would need to unplug multiple openings, which could be energetically costly (Biggins et al. 2012a). In nearby areas, complex burrow systems without surface plugs are likely available. The ferret might move to these other areas in search of burrows with multiple open-access holes, thereby reducing risk of predation for the resident prairie dogs that plugged the burrow openings. After the ferret departs, the prairie dogs are likely to remove the surface plugs, because the plugs reduce burrow connectivity and could increase vulnerability of the prairie dogs to predators or reduce burrow ventilation (Vogel et al. 1973). This suggests a cycle in which (1) prairie dogs plug burrows to deter a ferret, (2) the ferret removes the plugs to re-create multi-opening burrows (or to attack the prairie dogs), or the ferret moves elsewhere in search of complex burrow systems, and after the ferret moves elsewhere, (3) the prairie dogs unplug the burrows. In the ferret's new location, prairie dogs are likely to plug burrow openings, restarting the cycle in a new area of the colony.

This cycle could have at least 3 important implications in addition to those mentioned above. First, the cycle could result in spatial oscillations of surface plugs over time. The spatial dynamics of surface plugs (plugging and unplugging) could provide insight into movements by ferrets. Second, the cycle is likely to have energetic implications for both prairie dogs and ferrets (Biggins et al. 2012a, 2012b). Lastly, the burrow modifications likely influence burrow microclimates and, thus, could influence species that use prairie dog burrows, particularly those that are ineffective diggers (e.g., fleas that transmit the plague bacterium
Yersinia pestis-Biggins et al. 2012b). Future studies could investigate these interactions between prairie dogs and ferrets and the implications of the interactions for prairie dogs, ferrets, and associated species.

\section{Recommendations}

In the past, surface plugs have been used as a surrogate measure of ferret presence (Clark 1989). If managers use surveys to locate surface plugs, the utility of such surveys will depend on sizes of prairie dog colonies and the sampling method used. Random plots could be useful in smaller colonies. If larger colonies are of interest, surveys could include transects (e.g., Biggins et al. 2012b), or survey plots could be concentrated in different areas with high densities of burrow openings, particularly areas actively used by prairie dogs. Ferrets frequently use such areas (Eads et al. 2011a, 2011b).

\section{ACKNOWLEDGMENTS}

This study was made possible through State Wildlife Grant T35, study number 2435, provided by the South Dakota Department of Game, Fish and Parks. Support was also provided by the National Fish and Wildlife Foundation (Grant number 2006-0058-0000), the United States Fish and Wildlife Service, the United States Forest Service, the United States Geological Survey, the Denver Zoological Foundation, Prairie Wildlife Research, and the University of Missouri. Thanks also to J. Millspaugh and the following individuals (listed in alphabetical order) for support that assisted this and other studies of ferrets and prairie dogs on the study colony during 2007-2008: the Baysingers, P. Gober, R. Griebel, D. Jachowski, R. Jachowski, S. Larson, T. Livieri, D. Marsh, M. Reuber, A. Turgeon, S. and D. Webb, and the Wooden Knifes. Thanks also to B. Miller and 2 anonymous reviewers for constructive reviews of the manuscript, and to D. Heller for contributing his photograph to Fig. 1.

Any use of trade, product, or firm names is for descriptive purposes only and does not imply endorsement by the United States federal government.

\section{Literature Cited}

BigGINS, D.E. 2012. Use of multi-opening burrow systems by black-footed ferrets. Western North American Naturalist 72:134-139. 
Biggins, D.E., J.L. Godbey, M.R. Matchett, L.R. HaneBury, T.M. Livieri, and P.E. Marinari. 2006. Monitoring black-footed ferrets during reestablishment of free-ranging populations: discussion of alternative methods and recommended minimum standards. Pages 155-174 in J.E. Roelle, B.J. Miller, J.L. Godbey, and D.E. Biggins, editors, Recovery of the blackfooted ferret: progress and continuing challenges. U.S. Geological Survey Scientific Investigations Report 2005-5293.

Biggins, D.E., L.R. Hanebury, and K.A. Fagerstone. 2012a. Digging behaviors of radio-tagged black-footed ferrets near Meeteetse, Wyoming, 1981-1984. Western North American Naturalist 72:148-157.

Biggins, D.E., L.R. Hanebury, and B.J. Miller. 1991. Trial release of Siberian polecats (Mustela eversmanii). National Ecology Research Center Progress Report. 22 pp.

Biggins, D.E., B. Miller, L. Hanebury, R. Oakleaf, A. Farmer, R. Crete, and A. Dood. 1993. A technique for evaluating black-footed ferret habitat. Pages 73-78 in J. Oldemyer, B. Miller, and R. Crete, editors, Management of prairie dog complexes for reintroduction of the black-footed ferret. U.S. Fish and Wildlife Service Biological Report 13.

Biggins, D.E., S. Ramakrishnan, A.R. Goldberg, and D.A. EADS. 2012b. Black-footed ferrets and recreational shooting influence the attributes of blacktailed prairie dog burrows. Western North American Naturalist 72:158-171.

Bonham, C.D., AND R.M. Reich. 1999. Influence of spatial autocorrelation on a fixed-effect model used to evaluate treatment of oil spills. Applied Mathematics and Computation 106:149-162.

Chipault, J.G. 2010. Fine-scale habitat use by black-footed ferrets (Mustela nigripes) released on black-tailed prairie $\operatorname{dog}$ (Cynomys ludovicianus) colonies in New Mexico. Master's thesis, Colorado State University, Fort Collins, CO.

CLARK, T.W. 1989. Conservation biology of the black-footed ferret, Mustela nigripes. Wildlife Preservation Trust, Special Scientific Report No. 3.

Clark, T.W., T.M. Campbell III, D.G. Socha, and D.E. Casey. 1982. Prairie dog colony attributes and associated vertebrate species. Great Basin Naturalist 42:572-582.

ClifF, A.D., AND J.K. ORD. 1981. Spatial processes: models and applications. Pion Limited, London. 266 pp.

EADS, D.A. 2009. Evaluation and development of blackfooted ferret resource selection models. Master's thesis, University of Missouri, Columbia, MO.

Eads, D.A., D.S. Jachowski, J.J. Millspaugh, and D.E. BIGGINS. 2012a. Importance of lunar and temporal conditions for spotlight surveys of adult blackfooted ferrets. Western North American Naturalist 72:179-190

Eads, D.A., J.J. Millspaugh, D.E. Biggins, D.S. JachowsKi, AND T.M. LIVIERI. 2011a. Evaluation of a black-footed ferret resource utilization function model. Journal of Wildlife Management 75:1155-1163.

Eads, D.A., J.J. Millspaugh, D.E. Biggins, T.M. Livieri, AND D.S. JACHOWSKI. 2011b. Post-breeding resource selection by adult black-footed ferrets in the Conata Basin, South Dakota. Journal of Mammalogy 92 760-770.
ForTenbery, D.K. 1972. Characteristics of black-footed ferrets. U.S. Fish and Wildlife Service Resource Publication 109.

Henderson, F.R., P.F. Springer, and R. Adrian. 1969. The black-footed ferret in South Dakota. South Dakota Department of Game, Fish and Parks, Technical Bulletin 4:1-37.

Hillman, C.N. 1968. Life history and ecology of the black-footed ferret in the wild. Master's thesis, South Dakota State University, Brookings, SD.

HiLLMAN, C.N., AND R.L. LiNDER. 1973. The black-footed ferret. Pages 10-23 in R.L. Linder and C.N. Hillman, editors, Black-footed Ferret and Prairie Dog Workshop Proceedings. South Dakota State University, Brookings, SD.

HoogLAND, J.L. 1995. The black-tailed prairie dog: social life of a burrowing mammal. Chicago University Press, Chicago, IL.

JaChowsKi, D.S. 2007. Notes on black-footed ferret detectability and behavior. Prairie Naturalist 39:99-104.

Jachowski, D.S., J.J. Millspaugh, D.E. Biggins, T.M. Livieri, AND M.R. MatchetT. 2010. Home-range size and spatial organization of black-footed ferrets Mustela nigripes in South Dakota, USA. Wildlife Biology 16:1-11.

Johnson, W.C., AND S.K. Collinge. 2004. Landscape effects on black-tailed prairie dog colonies. Biological Conservation 115:487-497.

Kotliar, N.B., B.J. Miller, R.P. Reading, and T.W. Clark. 2006. The prairie dog as a keystone species. Pages 53-64 in J.L. Hoogland, editor, Conservation of the black-tailed prairie dog: saving North America's western grasslands. Island Press, Washington, DC.

Lichstein, J.W., T.R. Simons, S.A. Shriner, and K.E. FRANZREB. 2002. Spatial autocorrelation and autoregressive models in ecology. Ecological Monographs 72:445-463.

Livieri, T.M., AND E.M. ANDERSON. 2012. Black-footed ferret home ranges in Conata Basin, South Dakota. Western North American Naturalist 72:196-205.

Martin, S.J., M.H. Schroeder, and H. Tietjen. 1984. Burrow plugging by prairie dogs in response to Siberian polecats. Great Basin Naturalist 44:447-449.

McDonald, L.L. T.R. Stanley, D.L. Otis, D.E. Biggins, P.D. STEVENS, J.L. KoprowsKi, AND W. BaLLaRD. 2011. Recommended methods for range-wide monitoring of prairie dogs in the United States. U.S. Geological Survey Scientific Investigations Report 2011-5063.

Miller, B., R.P. Reading, and S. ForRest. 1996. Prairie night: black-footed ferrets and the recovery of endangered species. Smithsonian Institution Press, Washington, DC.

REICH, R.M., AND C.D. Bonham. 2001. Spatial analysis of grazed white bursage in the Lake Mead National Recreational Area, Nevada, USA. Grassland Science 47:128-133.

Vogel, S., C.P. Ellington, and D.L. Kilgore. 1973. Wind-induced ventilation of the burrow of the prairie-dog, Cynomys ludovicianus. Journal of Comparative Physiology 85:1-14.

Received 3 February 2012 Accepted 24 May 2012 